\title{
Efek Reputasi Kap dan Keterlambatan Laporan Auditor Independen Terhadap Ketepatan Waktu Penyampaian Laporan Keuangan
}

\author{
Zulkifli Umar ${ }^{1 *}$, Ermad M.J ${ }^{2}$, Dhea Adhima Suemdra ${ }^{3}$ \\ 1,2,3 Program Studi S1 Akuntansi, Fakultas Ekonomi, Universitas \\ Muhammadiyah Aceh, Kota Banda Aceh, Provinsi Aceh, Indonesia.
}

\begin{abstract}
Abstrak. Penelitian ini bertujuan untuk menguji efek reputasi kantor akuntan publik dan keterlambatan laporan auditor independen terhadap ketepatan waktu penyampaian laporan kenangan. Penelitian ini adalah penelitian sampel, yakni memasukan 225 perusahaan dari 510 perusabaan sektor manufaktur selama tabun pengamatan 2017-2019. Sampel dipilih dengan teknik simple random sampling, besaran sampel ditentukan dengan rumus slovin. Metode analisis yang digunakan adalah regresi logistik. Hasil penelitian menemukan babwa reputasi kantor akuntan publik berpengarub meningkatkan ketepatan waktu penyampaian laporan keuangan, khususnya kantor akuntan publik yang berafiliasi dengan Big 4. Keterlambatan laporan auditor independen juga berpengaruh terbadap ketepatan waktu penyampaian laporan kenangan, khususnya auditor yang tidak terlambat mneyampaiakan laporan auditor independennya.
\end{abstract}

Kata kunci: Reputasi Kantor Akuntan Publik; Keterlambatan Laporan Auditor Independen; Ketepatan Waktu Penyampaian Laporan Keuangan.

Abstract. This study aims to examine the effect of the reputation of the public accounting firm and the delay in the independent auditor's report on the timeliness of submitting financial statements. This research is a sample study, which includes 225 companies from 510 manufacturing sector companies during the 2017-2019 observation year. The sample was selected by simple random sampling technique, the sample size was determined by the slovin formula. The analytical method used is logistic regression. The results of the study found that the reputation of public accounting firms had an effect on increasing the timeliness of submitting financial reports, especially public accounting firms affiliated with the Big 4. The delay in the independent auditor's report also affects the timeliness of the financial report submission, especially the auditor who is not late in submitting the independent auditor's report.

Keywords: Reputation of Public Accounting Firms; Delays in Independent Auditor Reports; Timely Submission of Financial Reports. 


\section{Pendahuluan}

Ketepatan waktu penyampaian laporan keuangan diatur dalam peraturan Bapepam-LK Nomor: KEP-346/BL/2011 tentang Penyampaian Laporan Keuangan Emiten atau Perusahaan Publik. Peraturan tersebut menyatakan bahwa setiap perusahaan publik wajib menyampaikan laporan keuangan tahunan yang harus disertai dengan pendapat lazim dari auditor independen dan disampaikan kepada Bapepam selambat lambatnya pada akhir bulan ketiga (90 hari) setelah tanggal laporan keuangan tahunan perusahaan. Pengamatan awal terkait dengan ketepatan waktu penyampaian laporan keuangan dapat dilihat pada Tabel 1.

Tabel 1. Pengamatan Awal Ketepatan Waktu Penyampaian LK

\begin{tabular}{|c|l|l|l|l|}
\hline \multirow{2}{*}{ Tahun } & \multicolumn{3}{|c|}{ Tgl Penyampaian ke BEI } \\
\cline { 2 - 5 } & $<31$ Maret & \multicolumn{3}{|c|}{$>31$ Maret } \\
\cline { 2 - 5 } & PT & Persen & PT & Persen \\
\hline 2017 & 66 & $42 \%$ & 93 & $58 \%$ \\
\hline 2018 & 66 & $40 \%$ & 101 & $60 \%$ \\
\hline 2019 & 155 & $84 \%$ & 30 & $16 \%$ \\
\hline
\end{tabular}

Sumber: Idx.co.id, diolah tahun 2021

Berdasarkan Tabel 1 pengamatan awal ketepatan waktu penyampaian laporan keuangan ke Bursa Efek Indonesia (BEI) perusahaan manufaktur tahun 2017-2019 secara berurutan yaitu $58 \%, 60 \%$ dan 16\%. Hal ini menunjukan bahwa perusahaan sektor manufaktur mengalami fluktuatif dalam menyampaikan laporan keuangannya ke BEI. Paling menurun yaitu di tahun 2019, yaitu hanya $16 \%$ perusahaan sektor manufaktur yang tepat waktu menyampaikan laporan keuangannya ke BEI. Sisanya mengandung arti tidak tepat waktu dalam menyampaikan laporan keuangannnya ke BEI.

Berdasarkan survei literatur sebelumnya, terdapat beberapa faktor yang berpengaruh terhadap ketepatan waktu penyampaian laporan keuangan. Salah satu faktor tersebut yaitu reputasi kantor akuntan publik (Lourenco, Branco, \& Curto, 2018). Perusahaan dalam menyampaikan suatu laporan atau informasi akan kinerja perusahaan kepada publik harus akurat dan terpercaya, sehingga diminta untuk menggunakan jasa kantor akuntan publik. Untuk meningkatkan kredibilitas dari laporan tersebut, perusahaan pasti menggunakan jasa kantor akuntan publik yang mempunyai reputasi atau nama baik. Hal ini ditunjukkan dengan kantor akuntan publik yang berafiliansi dengan kantor akuntan publik besar, yang berlaku universal, yang dikenal dengan Big Four Worldwide Accounting Firm. Yang termasuk empat besar tersebut yaitu; Price Water House Coopers, Ernst \& Young, Klynveld Peat Marwick Goerdeler, dan Deloitte Touche Tohmatsu. KAP besar disebutkan memiliki akuntan yang berprilaku lebih etikal dari pada akuntan kecil (Abernathy et al., 2014). Sehingga akan dapat meningkatkan ketepatan waktu penyampaian laporan keuangan perusahaan.

Faktor berikutnya yang berdampak terhadap ketepatan waktu penyampaian laporan keuangan adalah keterlambatan laporan auditor independen. Keterlambatan laporan auditor independen merupakan terlambatnya auditor dalam menyampaikan laporan akhir hasil audit. Keterlambatan tersebut disebabkan oleh berbagai macam kendala dalam proses audit. Suatu laporan auditor independen dikatakan terlambat jika sudah melampaui batas waktu penyampaian laporan keuangan perusahaan. Dengan kata lain, jika auditor mengeluarkan laporan auditornya tiga bulan sejak akhir tahun buku perusahan, maka sudah dapat dikatakan terlambat. Auditor independen yang melakukan audit atas laporan keuangan berkewajiban untuk menyampaikan laporan akhir auditnya.

Laporan tersebut disampaikan setelah selesainya pekerjaan audit. Jika auditor mengalami kendala dalam pekerjaan auditnya, maka berpotensi laporannya juga terlambat disampaikan ke klien. Hal tersebut relevan dengan hasil penelitian Rahmayanti, (2016); dan Soares \& Amin, (2016). Mereka menemukan bahwa auditor yang mengalami keterlambatan laporan auditor independen akan berdampak terhadap terlambat juga penyerahannya kepada klien. Sehingga klien akan terlambat juga menyampaikan laporan keuangannya ke bursa. Hal ini menunjukan bahwa semakin tinggi keterlambatan laporan auditor independen, maka semakin rendah ketepatan waktu penyampaian laporan keuangan oleh perusahaan ke bursa. 
Atas menurunnya ketepatan waktu penyampaian laporan keunagan oleh perusahaan sektor manufaktur tahun 2019 yaitu hanya 16\% perusahaan sektor manufaktur yang tepat waktu menyampaikan laporan keuangannya ke bursa, maka tertarik untuk dilakukan penelitian Efek Reputasi Kantor Akuntan Publik dan Keterlambatan Laporan Auditor Independen terhadap Ketepatan Waktu Penyampaian Laporan Keuangan. Penelitian ini bertujuan untuk menguji Efek Reputasi Kantor Akuntan Publik dan Keterlambatan Laporan Auditor Independen terhadap Ketepatan Waktu Penyampaian Laporan Keuangan. Pembahasan artikel ini dimulai dari pendahuluan, literature review, kemudian dilanjutkan metode penelitian, hasil penelitian dan pembahasan, terakhir adalah kesimpulan

\section{Tinjauan Literatur}

\section{Hubungan Reputasi Kantor Akuntan Publik dengan Ketepatan Waktu Penyampaian Laporan Keuangan.}

Reputasi kantor akuntan publik memiliki hubungan dengan ketepatan waktu penyampaian laporan keuangan (Abernathy et al., 2014; Ahmad, Mohamed \& Nelson, 2016; Lourenco, Branco, \& Curto, 2018; dan Al Mulla \& Bradbury, 2020). Hubungan tersebut dapat dilihat dari peranan reputasi kantor akuntan publik atas ketepatan waktu penyampaian laporan keuangan. Perusahaan dalam menyampaikan suatu laporan atau informasi akan kinerja perusahaan kepada publik harus akurat dan terpercaya, sehingga diminta untuk menggunakan jasa kantor akuntan publik. Untuk meningkatkan kredibilitas dari laporan tersebut, perusahaan menggunakan jasa kantor akuntan publik yang mempunyai reputasi atau nama baik. Hal ini ditunjukkan dengan kantor akuntan publik yang berafiliansi dengan kantor akuntan publik besar, yang dikenal dengan Big Four Worldwide Accounting Firm. Yang termasuk empat besar tersebut yaitu Price Water House Coopers, Ernst \& Young, Klynveld Peat Marwick Goerdeler, dan Deloitte Touche Tohmatsu. KAP besar disebutkan memiliki akuntan yang berprilaku lebih etikal (Attarie,
2016). Sehingga akan dapat meningkatkan ketepatan waktu penyampaian laporan keuangan perusahaan.

Retupasi kantor akuntan publik memiliki hubungan positif dengan ketepatan waktu penyampaian laporan keuangan. Artinya bahwa ketika perusahaan memakai kantor akuntan publik yang bereputasi dalam mengaudit laporan keuangan mereka, maka pengguna laporan keuangan akan merespon positif, sehingga nilai perusahaan akan meningkat. Hal ini relevan dengan hasil penelitian yang ditemukan oleh Abernathy et al., (2014); Ahmad, Mohamed \& Nelson, (2016); Lourenco, Branco, \& Curto, (2018) dan Al Mulla \& Bradbury, (2020). Mereka menemukan bahwa reptuasi kantor akuntan publik dapat meningkatkan ketepatan waktu penyampaian laporan keuangan. Perusahaan yang menggunakan kantor akuntan publik yang bereputasi, maka akan dapat memaksimalkan kegiatan auditnya. Hal ini akan berdampak pada percepatan penyelesaian audit laporan keuangan, sehingga berdampak pada cepat juga perusahaan menyampaikan laporan keuangannya.

H1 : Reputasi kantor akuntan publik berpengaruh positif terhadap ketepatan waktu penyampaian laporan keuangan.

\section{Hubungan Keterlambatan Laporan Auditor Independen dengan Ketepatan Waktu Penyampaian Laporan Keuangan.}

Keterlambatan laporan auditor independen memiliki hubungan dengan ketepatan waktu penyampaian laporan keuangan (Rahmayanti, 2016; dan Soares \& Amin, 2016). Hal ini dapat dilihat dari peran keterlambatan laporan auditor independen atas ketepatan waktu penyampaian laporan keuangan. Auditor independen yang melakukan audit atas laporan keuangan berkewajiban untuk menyampaikan laporan akhir auditnya. Laporan tersebut disampaikan setelah selesainya pekerjaan audit. Jika auditor mengalami kendala dalam pekerjaan auditnya, maka berpotensi laporannya juga terlambat disampaikan ke klien. Hal tersebut relevan dengan hasil penelitian Rahmayanti, (2016); dan Soares \& Amin, (2016). Mereka menemukan bahwa auditor yang mengalami keterlambatan 
laporan auditor independen akan berdampak terhadap terlambat juga penyerahannya kepada klien. Sehingga klien akan terlambat juga menyampaikan laporan keuangannya ke bursa. Hal ini menunjukan bahwa semakin tinggi keterlambatan laporan auditor independen, maka semakin rendah ketepatan waktu penyampaian laporan keuangan oleh perusahaan ke bursa. Dengan kata lain keterlambatan laporan auditor independen berhubungan negatif dengan ketepatan waktu penyampaian laporan keuangan.

H2 : Keterlambatan laporan auditor independen berpengaruh negatif terhadap penyampaian laporan keuangan.

\section{Metodologi Penelitian}

Tujuan penelitian ini adalah untuk menguji efek reputasi kantor akuntan publik dan keterlambatan laporan auditor independen terhadap ketepatan waktu penyampaian laporan keungan. Jenis investigasi dalam penelitian ini adalah studi kausal. Intervensi peneliti dalam penelitian ini adalah intervensi minimal. Peneliti tidak ikut mempengaruhi fluktuasi penyampaian laporan keuangan perusahaan. Situasi studi dalam penelitian ini adalah tidak diatur. Artinya semua kegiatan di lingkungan pengamatan terjadi dengan normal dan alami tanpa adanya pengaturan dari penelti. Peneliti hanya mengumpulkan data dan selanjutnya menganalisis data tersebut untuk menjawab rumusan masalah dalam penelitian. Unit analisis dalam penelitian ini adalah perusahaan sektor manufaktur. Horizon waktunya adalah data panel periode pengamatan 2017-2019. Populasi dalam penelitian ini adalah perusahaan sektor manufaktur yang terdaftar di Bursa Efek Indonesia berjumlah 510 perusahaan selama tahun 2017-2019. Kemudian besaran sampel dipilih dengan rumus Slovin:

$$
\begin{aligned}
& \mathrm{n}=\frac{N}{1+N \cdot \mathrm{e}^{2}} \\
& \mathrm{n}=\frac{510}{1+\left(510 \times 0,05^{2}\right)} \\
& \mathrm{n}=\frac{510}{1+(510 \times 0,0025)}
\end{aligned}
$$

$\mathrm{n}=\frac{510}{2,27}$

$\mathrm{n}=224,66$

dibulatkan menjadi 225.

Berdasarkan perhitungan tersebut, maka jumlah sampel dalam penelitian ini berjumlah 225 perusahaan. Teknik pengambilan sampel dalam penelitian ini dilakukan dengan pengambilan sampel secara simple randong sampling.

Selanjutnya pengukuran variabel dalam penelitian ini yaitu reputasi kantor akuntan publik mengikuti Branco, \& Curto, (2018) diukur dengan kategori 0 untuk kantor akuntan publik yang tidak berafiliasi dengan Big 4, dan 1 untuk yang berafiliasi. Keterlambatan laporan auditor independen mengikuti Rahmayanti, (2016), diukur dengan kategori 0 untuk laporan auditor independen yang ditandatangani diatas tanggal 31 Maret tahun buku, dan 1 untuk laporan auditor independen yang ditandatangani di bawah tanggal 31 Maret tahun buku. Kemudian ketepatan waktu penyampaian laporan keuangan mengikuti Soares \& Amin, (2016), diukur dengan kategori 0 untuk perusahaan yang menyampaikan laporan keunagannya lebih dari 31 Maret tahun buku, dan 1 untuk yang melaporkan di bawah tanggal 31 Maret tahun buku. Metode analisis data yang digunakan dalam penelitian ini adalah regresi logistik. Kriteria yang digunakan adalah jika nilai signifikan lebih kecil dari tingkat signifikan, maka hipotesis alternatif diterima.

\section{Hasil dan Pembahasan Statistik Deskriptif}

Berdasarkan Tabel 2 tersebut, terlihat bahwa untuk variabel ketepatan waktu penyampaian laporan keuangan, selama tahun 2017-2019 mengalami fluktuasi dalam ketepatan waktu penyampaian laporan keuangannya. Tahun 2019 terdapat sebanyak $16,22 \%$ perusahaan sektor manufaktur yang tepat waktu menyampaikan laporan keuangannya. Kemudian, yang tidak tepat watktu justru sebanyak 83,78\% perusahaan. Hal ini menunjukan banyaknya perusahaan yang tidak tepat waktu menyampaikan laporan keuangan di tahun 2019 karena akhir tahun 2019 merupakan dimulainya Covid-19 di Indonesia. 
Tabel 2. Statistik Deskriptif

\begin{tabular}{|c|c|c|c|c|c|c|c|}
\hline & & \multicolumn{2}{|c|}{$\begin{array}{c}\text { Ketepatan Waktu } \\
\text { Penyampaian LK }\end{array}$} & \multicolumn{2}{c|}{ Reputasi KAP } & \multicolumn{2}{|c|}{$\begin{array}{c}\text { Keterlambatan Laporan } \\
\text { Auditor Independen }\end{array}$} \\
\cline { 3 - 8 } No. & \multirow{2}{*}{ Tahun } & $\begin{array}{c}\text { Tepat } \\
\text { Waktu }\end{array}$ & $\begin{array}{c}\text { Tidak Tepat } \\
\text { Waktu }\end{array}$ & Afiliasi Big 4 & $\begin{array}{c}\text { Non Afiliasi } \\
\text { Big 4 }\end{array}$ & $\begin{array}{c}<3 \text { bln } \\
\text { dari thn } \\
\text { buku }\end{array}$ & $\begin{array}{c}>3 \text { bln } \\
\text { dari thn } \\
\text { buku }\end{array}$ \\
\cline { 3 - 8 } & $(1)$ & $(0)$ & $(1)$ & $(0)$ & $(1)$ & $(0)$ \\
\hline 1. & 2017 & $58,49 \%$ & $41,51 \%$ & $38,99 \%$ & $61,01 \%$ & $89,94 \%$ & $10,06 \%$ \\
\hline 2. & 2018 & $60,48 \%$ & $39,52 \%$ & $33,53 \%$ & $66,47 \%$ & $91,62 \%$ & $8,38 \%$ \\
\hline 3. & 2019 & $16,22 \%$ & $83,78 \%$ & $32,43 \%$ & $67,57 \%$ & $60 \%$ & $40 \%$ \\
\hline
\end{tabular}

Reputasi KAP berdasarkan Tabel tersebut terlihat bahwa perusahaan yang menjadi pengamatan cenderung lebih sedikit menggunakan jasa KAP yang berafiliasi Big 4 . Seperti contohnya pada tahun 2019, hanya sebanyak $32,43 \%$ perusahaan yang menggunakan jasa akuntan publik yang berafiliasi Big 4, sedangkan sisanya sebesar $67,57 \%$ menggunakan akuntan publik tidak berafiliasi Big 4 .

Keterlambatan laporan auditor independen berdasarkan Tabel tersebut, menunjukan bahwa cenderung auditor independen tidak terlambat dalam mengeluarkan laporan auditor independennya. Hal ini seperti pada tahun 2019, ada $60 \%$ perusahaan yang telah menerima laporan auditor independen sebelum 3 bulan dari tahun buku. Hanya ada 40\% perusahaan yang menerima laporan auditor independen yang lebih dari 3 bulan dari tahun buku.

\section{Hasil Pengujian Goodness of Fit}

Pengujian goodness of fit dilakukan untuk menentukan apakah model yang dibentuk sudah tepat atau tidak. Dikatakan tepat apabilia tidak ada perbedaan yang signifikan antara mdoel dengan nilai observasi sebenarnya. Secara ringkas dapat dilihat pada Tabel 3.

Tabel 3. Hosmer and Lemeshow Test

\begin{tabular}{|c|c|c|c|}
\hline Step & Chi-square & df & Sig. \\
\hline 1 & 1.838 & 2 & 0.399 \\
\hline
\end{tabular}

Berdasarkan Tabel 2 terlihat Hosmer and Lemeshow Test memiliki nilai signifikan 0,399. Nilai ini menunjukan bahwa tidak ada perbedaan yang signifikan antara model dengan nilai obesevarsi yang sebenarnya. Dengan demikian, model dikatakan sudah tepat.

\section{Hasil Pengujian Hipotesis}

Hasil pengujian hipotesis dalam penelitian ini secara ringkas dapat dilihat pada Tabel Tabel 4.

Tabel 4. Hasil Pengujian Hipotesis

\begin{tabular}{|c|c|c|c|c|c|c|c|c|c|}
\hline \multicolumn{10}{|c|}{ Variables in the Equation } \\
\hline & & \multirow{2}{*}{ B } & \multirow{2}{*}{ S.E. } & \multirow{2}{*}{ Wald } & \multirow{2}{*}{ df } & \multirow{2}{*}{ Sig. } & \multirow{2}{*}{$\operatorname{Exp}(B)$} & \multicolumn{2}{|c|}{ 95,0\% C.I.for $\operatorname{EXP}(\mathrm{B})$} \\
\hline & & & & & & & & Lower & Upper \\
\hline \multirow[t]{3}{*}{ Step $1^{a}$} & $\mathrm{X} 1(1)$ & 0.743 & 0.212 & 12.326 & 1 & 0.000 & 2.101 & 1.388 & 3.181 \\
\hline & $\mathrm{X} 2(1)$ & 4.135 & 0.723 & 32.748 & 1 & 0.000 & 0.016 & 0.004 & 0.066 \\
\hline & Constant & 0.078 & 0.124 & 0.397 & 1 & 0.528 & 0.925 & - & - \\
\hline
\end{tabular}

Berdasarkan Tabel 4 terlihat nilai signifikan untuk masing-masing variabel $\mathrm{X}_{1}(1)$ yaitu reputasi KAP yang berkode 1. Artinya reputasi KAP yang memiliki afiliasi dengan Big 4 . Begitu juga nilai signifikan untuk variabel $\mathrm{X}_{2}(1)$ yaitu keterlambatan laporan auditor independen yang auditor tidak terlambat dalam menerbitkan laporan auditor independennya.

\section{Pengaruh Reputasi Kantor Akuntan Publik terhadap Ketepatan Waktu Penyampaian Laporan Keuangan}

Berdasarkan Tabel 4 terlihat nilai variabel $\mathrm{X}_{1}$ (1) yaitu reputasi KAP yang berkode 1. Artinya reputasi KAP yang memiliki afiliasi dengan Big 4 memiliki nilai signifikan sebesar 0,000 lebih kecil dari 0,005. Hal ini menunjukan bahwa hipotesis pertama diterima. Hal ini menunjukan 
bahwa reputasi KAP berpengaruh positif terhadap ketepatan waktu penyampaian laporan keuangan. Kemudian pada kolom $\operatorname{Exp}(\mathrm{B})$ terlihat nilai $\mathrm{X}_{1}(1)$ lebih besar dari 1 . Hal ini menunjukan bahwa reputasi KAP yang berafiliasi dengan Big 4 cenderung lebih besar berpengaruh terhadap ketepatan waktu penyampaian laporan keuangan dari pada dengan KAP yang non afiliasi dengan Big 4 .

Hasil penelitian ini relevan dengan Abernathy et al., (2014); Ahmad, Mohamed \& Nelson, (2016); Lourenco, Branco, \& Curto, (2018) dan Al Mulla \& Bradbury, (2020). Mereka menemukan bahwa reptuasi kantor akuntan publik dapat meningkatkan ketepatan waktu penyampaian laporan keuangan. Perusahaan yang menggunakan kantor akuntan publik yang bereputasi, maka akan dapat memaksimalkan kegiatan auditnya. Hal ini akan berdampak pada percepatan penyelesaian audit laporan keuangan, sehingga berdampak pada cepat juga perusahaan menyampaikan laporan keuangannya.

\section{Pengaruh Keterlambatan Laporan Auditor Independen terhadap Ketepatan Waktu Penyampaian Laporan Keuangan}

Berdasarkan Tabel 4 terlihat nilai variabel $\mathrm{X}_{2}(1)$ yaitu keterlambatan laporan auditor independen yang berkode 1. Artinya laporan auditor yang tidak terlambat memiliki nilai signifikan sebesar 0,000 lebih kecil 0,005. Hal ini menunjukan bahwa laporan auditor yang tidak terlambat berpengaruh positif terhadap ketepatan waktu penyampaian laporan keuangan. Kemudian pada kolom $\operatorname{Exp}(\mathrm{B})$ terlihat nilai $\mathrm{X}_{2}(1)$ sebesar 0,016 tidak lebih besar dari 1. Hal ini menunjukan bahwa laporan auditor yang terlambat (0) maupun yang tidak terlambat (1) tidak terdapat perbedaan yang berarti terhadap ketepatan waktu penyampaian laporan keuangan.

Hasil penelitian ini relevan dengan Rahmayanti, (2016); dan Soares \& Amin, (2016). Mereka menemukan bahwa auditor yang tidak terlambat mengeluarkan laporan auditor independen akan berdampak terhadap peningkatan penyerahannya kepada klien. Sehingga klien akan tepat waktu juga menyampaikan laporan keuangannya ke bursa. Hal ini menunjukan bahwa semakin tinggi ketepatan laporan auditor independen, maka semakin tinggi juga ketepatan waktu penyampaian laporan keuangan oleh perusahaan ke bursa.

\section{Koefisien Determinasi}

Besaran pengaruh variabel independen yang diteliti dalam penelitian ini terhadap variabel dependen, akan terlihat pada Tabel 5 .

Tabel 5. Model Summary

\begin{tabular}{|c|c|c|c|}
\hline Step & -2 Log likelihood & Cox \& Snell R Square & Nagelkerke R Square \\
\hline 1 & $567.954^{\mathrm{a}}$ & 0.229 & 0.306 \\
\hline
\end{tabular}

Berdasarkan Tabel 4 terlihat nilai Nagelkerke $R$ Square sebesar 0,306. Nilai ini menunjukan bahwa reputasi KAP dan keterlambatan laporan auditor independen hanya mampu mempengaruhi ketepatan watku penyampaian laporan keuangan sebesar 30,6\%. Sedangkan sisanya yaitu $60,4 \%$ dipengaruhi oleh variabel lain di luar dari penelitian ini.

\section{Kesimpulan}

Berdasarkan hasil penelitian yang telah diperoleh, reputasi KAP dan keterlambatan laporan auditor independen berpengaruh terhadap ketepatan waktu penyampaian laporan keuangan. KAP yang berafiliasi dengan Big 4 berpengaruh signifikan meningkatkan ketepatan waktu penyampaian laporan keuangan dari pada KAP yang berafiliasi Non Big 4. Sedangkan auditor yang tidak terlambat menyampaikan laporan auditor independen berpengaruh signifikan meningkatkan ketepatan waktu penyampaian laporan keuangan oleh perusahaan ke bursa.

Saran untuk perusahaan, agar tetap menggunakan jasa KAP yang berafiliasi Big 4 sebagai auditor eksternalnya. Hal ini karena ada pengaruh peningkatan ketepatan waktu penyampaian laporan keuangan oleh perusahaan ke bursa. Kemudian untuk penelitian selanjutnya agar menggunakan 
variabel lainnya yang berpengaruh terhadap ketepatan waktu penyampaian laporan keuangan.

\section{Daftar Pustaka}

Abernathy, J.L., Beyer, B., Masli, A., Stefaniak, C. (2014). The Association Between Characteristics of Audit Committee Accounting Experts, Audit Committee Chairs, and Fnancial Reporting Timeliness. Advances in Accounting, Incorporating Advances in International Accounting, 30:283-297. http://dx.doi.org/10.1016/j.adiac.2014.0 9.001

Ahmad, M., Mohamed, H., \& Nelson, S.P. (2016). The Association Between Industry Specialist Auditor and Financial Reporting Timeliness, Post MFRS Period. Procedia Social and Behavioral Sciences, 219:55-62. DOI: 10.1016/j.sbspro.2016.04.036

Al Mulla, M., \& Bradbury, M.E. (2020). The Demand and Supply Timely Financial Reports. Pacific Accounting Review, 32(3):335-353. DOI 10.1108/PAR-10 2018-0076

Hadi, M. (2018). Determinan Ketepatan Waktu Penyampaian Laporan Keuangan Manufaktur di Indonesia. Jurnal Riset Akuntansi dan Perpajakan, 5(1):77-85.

Lourenco, I.S., Branco, M.C., \& Curto, J.D. (2018). Timely Reporting and Family Ownership: the Portugal Case. Meditari Accountancy Research, 26(1):170-192. DOI 10.1108/PAR-10-2018-0076

Rahmayanti, D. (2016). Audit Delay, Profitabiltias, dan Kontribusinya terhadap Ketepatan Waktu Pelaporan Keuangan. Advance,3(1):12-26.
Republik Indonesia. Keputusan Ketua Badan Pengawas Pasar Modal dan Lembaga Keuangan Nomor. Kep-346/BL/2011 tentang Penyampaian Laporan Keuangan Berkala Emiten atau Perusahaan Publik.

Sakka, I.F., \& Jarboui, A. (2019). Audit Report Timeliness: Empirical Evidence from Tunisia. Cogent Business \& Management, 3:113.

DOI:10.1080/23311975.2016.1195680

Soares, M., \& Amin, M.N. (2016). Analisis Faktor-faktor yang Mempengaruhi Timeliness of Financial Reporting dengan Reputasi Auditor sebagai Variabel Moderasi atas Profitabiltias, Leverage, dan Umur Perusahaan, Studi Empiris pada Perusahaan Manufaktur yang Terdaftar di Bursa Efek Indonesia Periode 2010-2015. Jurnal Magister Akuntansi Trisakti, 3(2):121-146.

Sekaran, U. \& Bougie, R. (2017). Metodologi Penelitian untuk Bisnis, Pendekatan Pengembangan Keablian. Jilid 1 dan 2, Edisi 6. Jakarta: Salemba Empat.

Sembiring, Y.C.B. (2016). Pengaruh Rasio Leverage, dan Kepemilikan Publik terhadap Ketepatan Waktu Pelaporan Keuangan pada Perusahaan Manufaktur yang Terdaftar di Bursa Efek Indonesia. Jurnal Reviu Akuntansi dan Kenangan, 2(1):107-121.

Suryani, I., \& Pinem, D. (2018). Pengaruh Profitabilitas, Opini Auditor, dan Struktur Kepemilikan terhadap Ketepatan Waktu Penyampaian Laporan Keuangan. Accounting Research Journal of Staatmadja, 2(2):20-30 